\title{
Guillain-Barré Syndrome with Bilateral Peripheral Facial Nerve Paralysis After COVID-19 Infection
}

\author{
COVID-19 Enfeksiyonu Sonrası Guillain-Barré Sendromuna Bağlı Bilateral Periferik \\ Fasiyal Sinir Paralizisi
}

\author{
Canakkale Onsekiz Mart University Faculty of Medicine, Department of Neurology, Canakkale, Turkey
}

\begin{abstract}
Isolated bilateral peripheral facial paralysis in Guillain-Barré syndrome (GBS) is also quite rare. This case meets the diagnostic criteria of GBS with isolated bilateral peripheral facial paralysis following the coronavirus disease-2019 (COVID-19) infection. A 48-year-old male patient with bilateral peripheral facial nerve paralysis on neurological examination and without other abnormalities was admitted to the emergency department, 18 days after a COVID-19 infection. An increase in cell-free protein (albuminocytological dissociation) in the patient's cerebrospinal fluid and demyelinating polyneuropathy in electrophysiological examinations suggested GBS in the patient. Facial paralysis findings were completely resolved after 5 days of intravenous immune globulin therapy. Physicians must closely monitor patients' neurological signs because of the possible association between GBS and COVID-19.
\end{abstract}

Keywords: Guillain-Barré syndrome, COVID-19, bilateral peripheral facial paralysis

Öz

İzole bilateral periferik yüz felci Guillain-Barré sendorumunda (GBS) oldukça nadirdir. Burada koronavirüs hastalığı-2019 (COVID-19) enfeksiyonu sonrası GBS'sine bağlı izole bilateral periferik fasiyal sinir paralizisi tanı kriterlerini karşılayan bir olgu sunulmuştur. Nörolojik muayenesinde bilateral periferik fasiyal sinir paralzisi olan 48 yaşındaki erkek hasta, COVID-19 enfeksiyonundan 18 gün sonra acil servise başvurdu. Beyin omurilik sıvısında yüksek protein içeriği mevcuttu ve elektromiyografi bulguları demiyelinizan polinöropati düşündürüyordu. Yüz felci bulguları beş günlük intravenöz immünoglobulin tedavisinden sonra tamamen düzeldi. GBS ve COVID-19 arasındaki olası ilişki nedeniyle, COVID-19 hastalarında nörolojik belirtilerin yakından izlemesi önemlidir.

Anahtar Kelimeler: Guillain-Barré sendromu, COVID-19, bilateral periferik fasiyal sinir paralizisi

\section{Introduction}

Coronavirus disease-2019 (COVID-19) is a highly contagious disease caused by the new coronavirus, severe acute respiratory syndrome-coronavirus-2. Small series and single cases of GuillainBarré syndrome (GBS) were published during the COVID-19 outbreak. Isolated peripheral bilateral facial paralysis in GBS cases secondary to COVID-19 infection was rarely reported. Most patients with GBS due to the COVID-19 infection were elderly men. Weakness in the limbs and acute flaccid quadriparesis and demyelinating polyneuropathy was commonly observed in most of these reports (1).

A case meeting the diagnostic criteria of Wakerley et al. (2) and a review of GBS cases with bilateral facial paralysis following COVID-19 infection is presented.

\section{Case Report}

A 48-year-old male patient was admitted to the emergency department due to facial weakness on both sides and difficulty in closing his eyes. A real-time polymerase chain reaction test for COVID-19 was conducted 18 days ago at the hospital where he was admitted with a sore throat and fever, which revealed positive results. His thoracic computed tomography (CT) results were compatible with COVID-19. Eight days after being discharged, the patient complained of buzzing in the ears, unpleasant sensations in the mouth, and weakness in the facial muscles. The patient had a good general condition, clear consciousness, full co-operation and orientation, and normal vital signs. He did not smoke and drink alcohol.

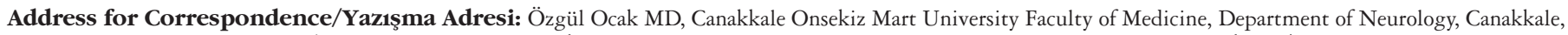
Turkey Phone: +90 5058320631 E-mail: dr_ozgul@hotmail.com ORCID: orcid.org/0000-0001-8276-0174 Received/Geliş Tarihi: 02.02 .2021 Accepted/Kabul Tarihi: 02.11.2021

${ }^{\circ}$ Copyright 2021 by Turkish Neurological Society Turkish Journal of Neurology published by Galenos Publishing House.
} 
His neurological examination revealed bilateral peripheral facial nerve paralysis (inability to close both eyelids, difficulty eating and speaking, wiping both nasolabial grooves, and inability to wrinkle his forehead) (Figure 1). No other abnormalities were found in his other cranial nerves, neurological, and system examinations. A complete blood count is normal, and no pathology was detected in biochemistry tests. The brain CT and brain magnetic resonance imaging revealed normal results. The cerebrospinal fluid (CSF) examination revealed normal pressure, clear appearance, protein of 2,858 mg/l (normal value: 150-450 $\mathrm{mg} / \mathrm{l})$, and other parameters within normal limits. No cells and microorganisms were seen in the CSF microscopic examination. An electromyographic (EMG) nerve conduction study revealed increased distal motor latency and decreased sensory and motor nerve conduction velocity in the evaluated nerves. Bilateral R1 and R2 potentials are absent. These findings suggest demyelinating polyneuropathy and are compatible with GBS diagnosis.

Based on these clinical, imaging and laboratory findings, the patient was considered to have GBS and was admitted to the neurology service. Lyme immunoglobulin ( $\mathrm{Ig}) \mathrm{G}$ and IgM, venereal disease research laboratory, herpes simplex virus, and varicella-zoster virus tests were negative. Angiotensin-converting enzyme activity in the blood was found to be normal. The patient was given intravenous $\mathrm{Ig}$ at $0.4 \mathrm{~g} / \mathrm{kg}$ for 5 days, in addition to refreshing tears and eye-protective visco tears gel four times daily.
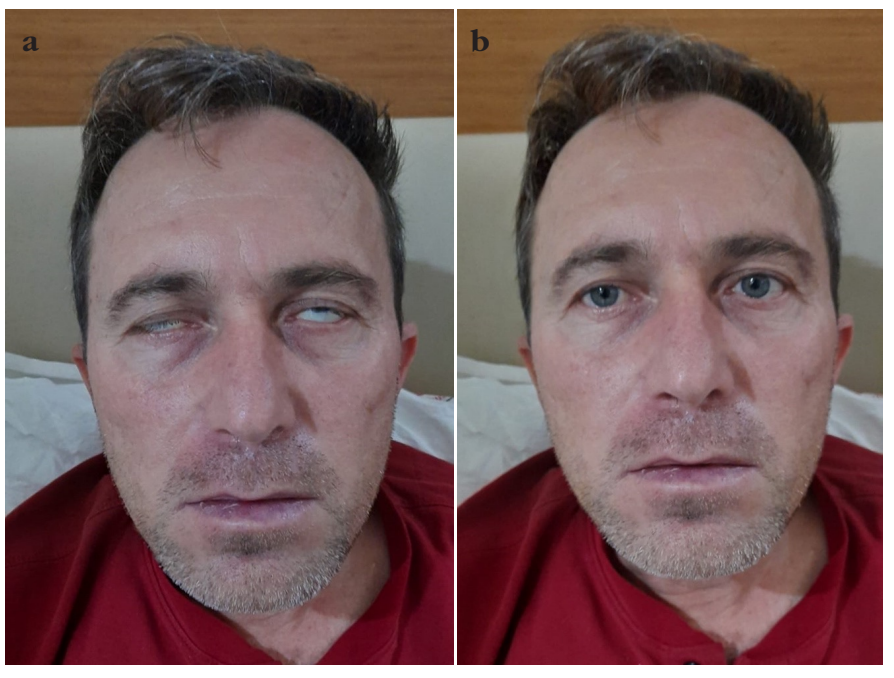

Figure 1a, b. Facial image of the patient showing bilateral peripheral facial nerve paralysis

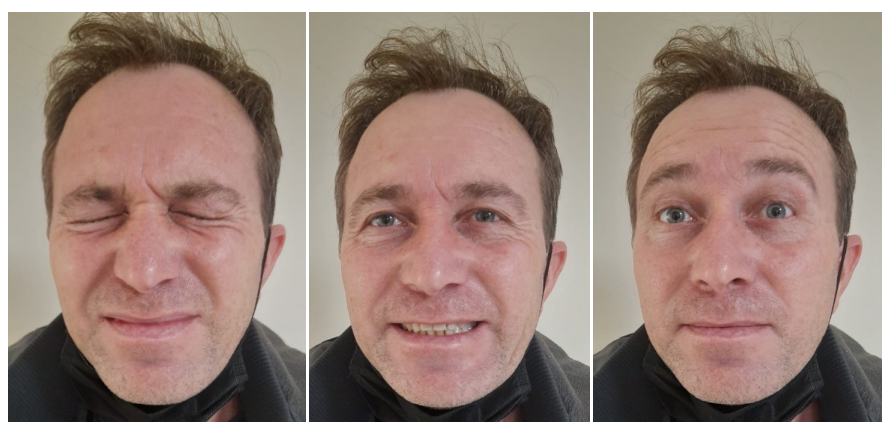

Figure 2a, b, c. Facial image of the patient after treatment. Facial paralysis findings were completely resolved
Facial paralysis findings were completely resolved in the patient who was followed up after 10 days (Figure 2).

\section{Discussion}

The most common causes of bilateral peripheral facial paralysis are GBS, Lyme disease, Bell's palsy, skull fracture, syndrome, multiple sclerosis, and infectious mononucleosis. GBS is an acute inflammatory immune disease of the nerve roots of the peripheral nerves. It is an acquired acute polyradiculoneuropathy that usually shows progressive flask paralysis and is characterized by widespread sensory, motor, and autonomic symptoms, which lead to deep tendon reflex reduction. The majority of cases are present with symmetric muscle weakness and areflexia. Rare variants of GBS, such as facial diplegia paresthesia that are associated with ganglioside antibodies, have been reported (3).

GBS is usually diagnosed based on clinical criteria. In addition, changes in EMG and albuminocytological dissociation in CSF examinations help to confirm the diagnosis of GBS.

GBS is preceded by symptomatic infections, such as campylobacter jejuni, Epstein-Barr virus, influenza, or cytomegalovirus, in approximately two-thirds of cases. Some antibodies on pathogens were suggested to show similarities with peripheral nerve components, and autoimmune processes triggered by this may play a role in the development of GBS after infections. Similarities between peptides of pathogen origin and nerve tissue can theoretically cross-react through cellular immunity (1).

Bilateral facial nerve paralysis is rare and accounts for $0.3-2 \%$ of all patients with paralysis (4). Many infectious agents, including the cytomegalovirus, Epstein-Barr virus, human immunodeficiency virus, $\mathrm{ZiKa}$ virus, and Campylobacter jejuni, have been associated with GBS. Some case reports of COVID-19-related GBS were also reported (5). A study reported that facial paralysis may be the only manifestation of COVID-19, and infection was present in $24.3 \%$ of the examined facial paralysis cases (6). Coronaviruses were thought to cause GBS directly through ACE2 receptors in the neuronal tissues or indirectly through the immune system response $(7,8)$.

Bilateral facial paralysis without the acute onset of extreme weakness and another cranial neuropathy is rarely observed but should be considered if observed in GBS. A case of delayed facial palsy was also reported as a rare manifestation of GBS although mostly observed in early phases (9). Diagnosis of acute onset bifacial weakness secondary to GBS can only be made based on history and examination (Table 1). In the presented case, GBS diagnosis was considered based on electrophysiological findings that were consistent with demyelinating polyneuropathy and CSF findings, which show albuminocytological dissociation.

A limited number of cases of GBS with bilateral peripheral facial paralysis have been reported so far. A 61-year-old male patient first developed right peripheral facial paralysis followed by bilateral facial paralysis (10). A 56-year-old female (11), a 21-year-old male (12), a 43-year-old male (13), and a 38-year-old male patient (14) reported bilateral peripheral facial paralysis, as well as loss of strength in the extremities. One female patient was reported as a GBS case with unilateral peripheral facial paralysis (15). A reported case is accompanied by ataxia, as well as bilateral peripheral facial paralysis (16). A 44-year-old male patient was reported with bilateral peripheral facial paralysis and GBS, but deep tendon reflexes were preserved (17). Only one case met the Wakerley diagnostic criteria, with bilateral peripheral facial 
Table 1. Diagnostic criteria for Guillain-Barré syndrome with isolated bilateral facial paralysis [modified from Wakerley et al. (2)]

Core features

- Facial weakness* and areflexia/hiporeflexia†

- Absence of ophthalmoplegia, ataxia, and limb or neck weakness

- Monophasic disease course with an interval between onset and nadir of the weakness of $12 \mathrm{~h}$ to 28 days, followed by a clinical plateau

Supportive features

- Antecedent infectious symptomsł

- Presence of distal paresthesia at or before the onset of weakness

- Electrophysiological evidence of neuropathy

- Cerebrospinal fluid albuminocytological dissociation』

*Weakness may be asymmetric, †Muscle stretch reflexes may be normal, ‡Such as the presence of upper respiratory infection symptoms or diarrhea 3 days to 6 weeks before the onset of neurological symptoms, lCerebrospinal fluid with a total white cell count of $<50$ cells $/ \mu$ l and protein above the normal laboratory range

weakness and areflexia on neurological examination, was reported (18). In this case, no abnormality was detected except for bilateral peripheral facial nerve palsy on examination.

Case reports of GBS associated with COVID-19 infection are reported worldwide. However, more data and further research are still necessary on this subject. Physicians must closely monitor patients' neurological signs because of the possible association between GBS and COVID-19. Bilateral peripheral facial paralysis in GBS is also quite rare. Most cases of bilateral peripheral facial paralysis that are reported in the COVID-19 pandemic did not meet the diagnostic criteria and with isolated bilateral peripheral facial paralysis.

\section{Ethics}

Informed Consent: Informed consent was obtained.

Peer-review: Externally peer-reviewed.

Financial Disclosure: The author declared that this study received no financial support.

\section{References}

1. Rahimi K. Guillain-Barre syndrome during COVID-19 pandemic: an overview of the reports. Neurol Sci 2020;41:3149-3156.

2. Wakerley B, Uncini A, Yuki N, et al. GBS Classification Group. GuillainBarré and Miller Fisher syndromes-new diagnostic classification. Nat Rev Neurol 2014;10:537-544.

3. Akarsu EA, Yalçın D, Sürmeli R, et al. A rare variant of Guillain-Barre Syndrome: facial diplegia paresthesia. Turk J Neurol 2015;21:171-174.

4. Sharma OP. Neurosarcoidosis: a personal perspective based on the study of 37 patients. Chest 1997;112:220-228.

5. Ottaviani D, Boso F, Tranquillini E, et al. Early Guillain-Barré syndrome in corona virus disease 2019 (COVID-19): a case report from an Italian COVIDhospital. Neurol Sci 2020;41:1351-1354.

6. Islamoglu Y, Celik B, Kiris M. Facial paralysis as the only symptom of COVID-19: A prospective study. Am J Otolaryngol 2021;42:102956.

7. Zhou Z, Kang H, Li S, Zhao X. Understanding the neurotropic characteristics of SARS-CoV-2: from neurological manifestations of COVID-19 to potential neurotropic mechanisms. J Neurol 2020;267:2179-2184.

8. Zhao H, Shen D, Zhou H, Liu J, Chen S. Guillain-Barré syndrome associated with SARS-CoV-2 infection: causality or coincidence? Lancet Neurol 2020;19:383-384.

9. Huang $\mathrm{X}$, Lan Z, Zhan $\mathrm{Y}, \mathrm{Hu}$ Z. Case report and literature analysis: Guillain-Barré Syndrome with delayed unilateral facial palsy. Front Neurol 2021;12:658266.

10. Juliao Caamaño DS, Alonso Beato R. Facial diplegia, a possible atypical variant of Guillain-Barré Syndrome as a rare neurological complication of SARS-CoV-2. J Clin Neurosci 2020;77:230-232.

11. Pelea T, Reuter U, Schmidt C, et al. SARS-CoV-2 associated Guillain-Barré syndrome. J Neurol 2021;268:1191-1194.

12. Hutchins KL, Jansen JH, Comer AD, et al. COVID-19-Associated Bifacial Weakness with Paresthesia Subtype of Guillain-Barré Syndrome. AJNR Am J Neuroradiol 2020;41:1707-1711.

13. Velayos Galán A, Del Saz Saucedo P, Peinado Postigo F, Botia Paniagua E. Guillain-Barré syndrome associated with SARS-CoV-2 infection. Neurologia (Engl Ed) 2020;35:268-269. (English, Spanish)

14. Paybast S, Gorji R, Mavandadi S. Guillain-Barré syndrome as a neurological complication of novel covid-19 infection: a case report and review of the literature. Neurologist 2020;25:101-103.

15. Ottaviani D, Boso F, Tranquillini E, et al. Early Guillain-Barré syndrome in coronavirus disease 2019 (COVID-19): a case report from an Italian COVIDhospital. Neurol Sci 2020;41:1351-1354.

16. Toscana G, Palmerini F, Ravaglia S, et al. Guillain-Barré Syndrome Associated with SARS-CoV-2. N Engl J Med 2020;382:2574-2576.

17. Khaja M, Gomez GPR, Santana Y, et al. A 44-Year-Old Hispanic Man with Loss of Taste and Bilateral Facial Weakness Diagnosed with Guillain-Barré Syndrome and Bell's Palsy Associated with SARS-CoV-2 Infection Treated with Intravenous Immunoglobulin. Am J Case Rep 2020;21:e927956.

18. Chan JL, Ebadi H, Sarna JR. Guillain-Barré Syndrome with Facial Diplegia Related to SARS-CoV-2 Infection. Can J Neurol Sci 2020;47:852-854. 